\title{
IMPACT OF SERVICE MARKETING MIX ON CUSTOMER SATISFACTION
}

\author{
M. B. M. Ismail, \\ Department of Management, \\ South Eastern University of Sri Lanka, \\ mbmismail1974@gmail.com \\ K. M. Mubarack, \\ Department of Management, \\ South Eastern University of Sri Lanka. \\ M. Z. Thulkifly, \\ Student \\ Department of Management, \\ South Eastern University of Sri Lanka
}

\begin{abstract}
Findings of previous studies poorly proved that the impact of all elements of service marketing mix on customer satisfaction. This gap motivated me to do research in banking services to know the impact of service marketing mix on customer satisfaction in two selected branches of Batticaloa District. This study is aimed to know the impact of service marketing mix on customer satisfaction. This study considered 100 banking customers from the selected two branches of Bank of Ceylon in Batticaloa District. For collecting data, questionnires were distributed among the customer for each branch of Bank of Ceylon during the banking hours without disturbing the employees at banks. In this study, if correlation values for service marketing mix elements such as product, place, promotion, price, people, process \& physical evidence and customer satisfaction are $0.707,0.605,0.685,0.665,0.684,0.504$ and 0.670 respectively service marketing mix elements have higher strength of associations with customer satisfaction. Test of hypotheses have proved that service marketing mix has relationship with customer satisfaction. In terms of the values of the $R$ square and adjusted $R$ square of the results of the regression, service marketing mix elements such as product, place, promotion, price, people, process and physical evidence explain around 75\% of variation on customer satisfaction. Study concludes that service marketing mix have higher impact on customer satisfaction.
\end{abstract}

Keywords: Bank, Customer, Marketing, Mix, Satisfaction, Service.

\section{Introduction}

Service marketing mix focuses on the needs of the customers in the banking sector. Service marketing mix is as a tool for achieving the customer-orientation in practice. Service marketing mix such as product, price, place, promotion, people, process and physical evidence are instrumental in satisfying the needs of customers (Kotler, 2003). These are number 
of studies with respect to the relationship between few selected elements of service marketing mix and customer satisfaction. Dixit (2004) studied about successful and effective on marketing. Study found that the design of new products that meet customers' need and well-equipped staff with adequate knowledge. Study also found that long-term strategies should be adopted to convert the entire organization into a customer-oriented one. In another research conducted by Gupta and Mittal (2008), it was found that it is very important to have a well-designed promotional strategy to promote banking services effectively to satisfy customers. There are also studies that highlight promotional influence on customer deposits. Rao (1982) conducted a study to find out the influence of different media of advertisement and different forms of personal selling on the deposit mobilization of commercial banks both in urban and rural areas. Study found that usage of print media has no impact on the rural deposit customers. Study also found that personal selling is a more powerful promotional method to promote deposit customers of all types. Findings of the previous studies found that service marketing mix is indispensable in promoting customer satisfaction in different service industries. But, these findings did not properly support the impact of all elements of service marketing mix on customer satisfaction. This gap motivated me to do research in banking services to know the impact of service marketing mix on customer satisfaction in two selected branches of Batticaloa District. This research is undertaken into two branches such as Batticaloa branch and Kattankudy branch of Bank of Ceylon in Batticaloa District.

\section{Research Question and Objective}

Researcher raises "is there impact of service marketing mix on customer satisfaction" as research question. This research question is translated into research objective termed as "to know the impact of service marketing mix on customer satisfaction".

\section{Significance of the Study}

Studies found that banking industry has become extremely competitive in today's World. Nowadays, service marketing mix creates the more opportunity for maintaining existing customers and attracting new customers that provides satisfied customers. Studies found that customer satisfaction is important to get enough price payment. Homburg, et. al., (2005) conducted a study to find the relationship between customer satisfaction and willingness to pay. The study revealed the existence of a positive impact of customer satisfaction on willingness to pay. Findings of previous studies proved that service marketing mix is crucial for competitive advantage. Al-Debi and Mustafa (2014) found that there is impact of services marketing 7 Ps such as such as product, price, place, promotion, people, physical evidence, and process in the achieving of competitive advantage in five stars hotels in Jordan. This study is significant this is because service marketing mix improves the conditions of cooperative shops. Study conducted by Yasanallah and Vahid (2012) found that the marketing mix (7Ps) improved the conditions of such cooperatives in cooperative shops.

\section{Review of Literature}

For this study, numbers of previous researches 
were reviewed. Ismail and Safrana (2015) found that the marketing strategy has impact on customerretention inhandloomindustry. Results of multiple linear regression analysis revealed that value of adjusted $\mathrm{R}$ square equals 0.728 explaining around $73 \%$ of variation. Marketing mix such as product, price, place and promotion explain around $73 \%$ of variation on customer retention. Ismail and Velnampy (2014) studied about marketing mix of product life cycle and business performance for sarong of Royal Handloom Weaving Factory. Results showed that product mix and distribution mix affect/ influences positively business performance. Ismail (2014) studied about product mix and sales maximization of rice mill entrepreneurs in Ampara Coastal Area of Eastern Province of Sri Lanka. Study revealed that product mix of a variety of rice brands has relationship with sales maximization. Ismail (2014) found that there is an influence of consumer promotional budget on sales in retail marketing. Results of the correlations between sales, total consumer promotional budget, total cost and revenue are greater than 0.790 . Findings revealed that only advertisement and public relation influence on sales in retail marketing. Ismail (2012) studied about corporate social responsibility in People's Bank of Sri Lanka. Ismail (2012) studied about service quality and bank client satisfaction in South Eastern Region of Sri Lanka. Ismail (2012) studied about service quality and bank client satisfaction in South Eastern Region (SER) of Sri Lanka. Ismail (2010) studied about determinants of retail customer satisfaction in banking industry in the Eastern Province of Sri Lanka.
Mehta (2010) studied about the lack of marketing communication that exists in Indian Banks. Study found that banks have to adopt suitable promotion strategies for better business to attract customers. Study found that personal selling is a strategy for marketing promotion that banks can improve its customer and business base. Kola and Akinyele (2010) studied about advertising \& personal selling that has moderate impact on customer's information, awareness, attitudes, company image- building and brand loyalty in the Nigerian service sectors. Goerge and Kostis (2005) conducted the study on pricing objectives and pricing methods in the services sector. Findings of the study revealed that the pricing objectives and pricing methods influence on the company's customers. Meidan (1976) revealed that about 90 percent of the respondents banked at the branch nearest to their home or work place. Convenience location was found to be the single most important factor for selecting a branch. Sarker, et. al., (2012) conducted a study to examine the impact of marketing mix elements on tourists' satisfaction. The study showed that marketing mix elements such as product, place, promotion, people, process and physical evidences were positively related to tourists' satisfaction except price element. Al-Muala and Al-Qurnch (2012) found that product, place, price, personnel and process have significant impact on tourists' satisfaction.

\section{Conceptual Model}

The above findings and the reviews of literature helped the researcher to derive the following conceptual model. 


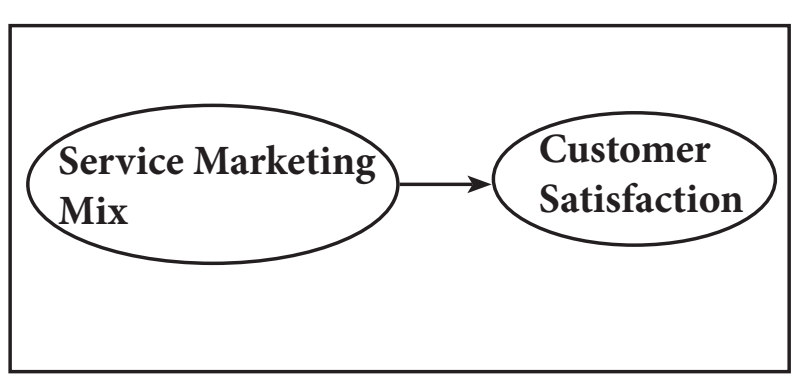

Figure 1: Conceptual Model

(Source: Review of Literature and Ismail, 2016)

\section{Hypotheses Development}

Based on the review of literature and the conceptual model, the following null and alternative hypotheses are developed.

Null hypothesis: Service marketing mix is not related to customer satisfaction

Alternative hypothesis: Service marketing mix is related to customer satisfaction

\section{Methodology}

\section{Sample size}

This study considered 100 banking customers from the selected two branches of Bank of Ceylon in Batticaloa District.

\section{Method of Data Collection}

Primary source of data are used for the present study. Primary data source is the questionnaire. For collecting data, questionnires were distributed among the customer for each branch of Bank of Ceylon during the banking hours without disturbing the employees at banks.

\section{Techniques of Data Analysis}

Collected data were analysed with several techniques such as correlation and regression.

\section{Results and Discussion of Findings Correlation Analysis}

Studies have found that there are different values for Pearson correlation. Based on the values of Pearson correlation, the strength of association between variables vary. Altman and Bland (1983) stated that the Pearson correlation coefficient, $r$, can take a range of values from +1 to -1 . A value of 0 indicates that there is no association between the two variables. A value that is greater than 0 indicates a positive association. That is, as the value of one variable increases, so does the value of the other variable. A value that is less than 0 indicates a negative association. That is, as the value of one variable increases, the value of the other variable decreases. Hinkle, Wiersma and Jurs (2003) highlighted that the stronger the association of the two variables, the closer the Pearson correlation coefficient, $r$, will be to either +1 or -1 depending on whether the relationship is positive or negative, respectively. Achieving a value of +1 or -1 means that all your data points are included on the line of best fit - there are no data points that show any variation away from this line. Values for $r$ between +1 and -1 (for example, $r=0.8$ or -0.4 ) indicate that there is variation around the line of best fit. The closer the value of $r$ to 0 the greater the variation around the line of best fit. Altman and Bland (1983); Hinkle, Wiersma and Jurs (2003) have categorized the Pearson correlations into three major categories such as small, medium and large. These values are tabulated in Table 1. 
Impact of Service Marketing Mix on Customer Satisfaction

Table 1: Correlation Coefficient

\begin{tabular}{|l|c|c|}
\hline & \multicolumn{2}{|c|}{ Coefficient, $r$} \\
\hline Strength of Association & Positive & Negative \\
\hline Small & 0.1 to 0.3 & -0.1 to -0.3 \\
\hline Medium & 0.3 to 0.5 & -0.3 to -0.5 \\
\hline Large & 0.5 to 1.0 & -0.5 to -1.0 \\
\hline
\end{tabular}

(Source: Altman and Bland, 1983; Hinkle, Wiersma and Jurs, 2003, Ismail, 2015)

In this study, correlations have been calculated promotion, price, people, process \& physical between service marketing mix elements such evidence and customer satisfaction are 0.707, as product, place, promotion, price, people, 0.605, 0.685, 0.665, 0.684, 0.504 and 0.670 process \& physical evidence and customer respectively. Table 2 tabulates the correlation satisfaction. Correlation values for service values. Since all these correlation values for marketing mix elements such as product, place, service marketing mix elements such as product,

Table 2: Correlations

\begin{tabular}{|c|c|c|c|c|c|c|c|c|c|}
\hline & & Product & Place & promotion & Price & people & process & $\begin{array}{l}\text { Physical } \\
\text { evidence }\end{array}$ & $\begin{array}{l}\text { Customer } \\
\text { satisfaction }\end{array}$ \\
\hline \multirow[t]{3}{*}{ Product } & Pearson Correlation & 1 & $.549^{* *}$ & $.390^{* *}$ & $.371^{* *}$ & $.425^{* *}$ & $.234^{*}$ & $.322^{* *}$ & $.707^{* *}$ \\
\hline & Sig. (2-tailed) & & .000 & .000 & .000 & .000 & .019 & .001 & .000 \\
\hline & $\mathrm{N}$ & 100 & 100 & 100 & 100 & 100 & 100 & 100 & 100 \\
\hline \multirow[t]{3}{*}{ Place } & Pearson Correlation & $.549^{* *}$ & 1 & $.277^{* *}$ & $.322^{* *}$ & $.371^{* *}$ & .176 & $.290^{* *}$ & $.605^{\star \star}$ \\
\hline & Sig. (2-tailed) & .000 & & .005 & .001 & .000 & .080 & .003 & .000 \\
\hline & $\mathrm{N}$ & 100 & 100 & 100 & 100 & 100 & 100 & 100 & 100 \\
\hline \multirow[t]{3}{*}{ Promotion } & Pearson Correlation & $.390^{* *}$ & $.277^{* *}$ & 1 & $.352^{* *}$ & $.495^{\star *}$ & $.305^{* *}$ & $.469^{* *}$ & $.685^{* *}$ \\
\hline & Sig. (2-tailed) & .000 & .005 & & .000 & .000 & .002 & .000 & .000 \\
\hline & $\mathrm{N}$ & 100 & 100 & 100 & 100 & 100 & 100 & 100 & 100 \\
\hline \multirow[t]{3}{*}{ Price } & Pearson Correlation & $.371^{* *}$ & $.322^{* *}$ & $.352^{* *}$ & 1 & $.315^{* *}$ & $.306^{* *}$ & $.470^{* *}$ & $.665^{* *}$ \\
\hline & Sig. (2-tailed) & .000 & .001 & .000 & & .001 & .002 & .000 & .000 \\
\hline & $\mathrm{N}$ & 100 & 100 & 100 & 100 & 100 & 100 & 100 & 100 \\
\hline \multirow[t]{3}{*}{ People } & Pearson Correlation & $.425^{* *}$ & $.371^{* *}$ & $.495^{* *}$ & $.315^{* *}$ & 1 & $.341^{* *}$ & $.459^{* *}$ & $.684^{* *}$ \\
\hline & Sig. (2-tailed) & .000 & .000 & .000 & .001 & & .001 & .000 & .000 \\
\hline & $\mathrm{N}$ & 100 & 100 & 100 & 100 & 100 & 100 & 100 & 100 \\
\hline \multirow[t]{3}{*}{ Process } & Pearson Correlation & $.234^{*}$ & .176 & $.305^{* *}$ & $.306^{* *}$ & $.341^{* *}$ & 1 & .180 & $.504^{* *}$ \\
\hline & Sig. (2-tailed) & .019 & .080 & .002 & .002 & .001 & & .073 & .000 \\
\hline & $\mathrm{N}$ & 100 & 100 & 100 & 100 & 100 & 100 & 100 & 100 \\
\hline \multirow{3}{*}{$\begin{array}{l}\text { Physical } \\
\text { evidence }\end{array}$} & Pearson Correlation & $.322^{* *}$ & $.290^{* *}$ & $.469^{* *}$ & $.470^{* *}$ & $.459^{* *}$ & .180 & 1 & $.670^{* *}$ \\
\hline & Sig. (2-tailed) & .001 & .003 & .000 & .000 & .000 & .073 & & .000 \\
\hline & $\mathrm{N}$ & 100 & 100 & 100 & 100 & 100 & 100 & 100 & 100 \\
\hline \multirow{3}{*}{$\begin{array}{l}\text { Customer } \\
\text { satisfac- } \\
\text { tion }\end{array}$} & Pearson Correlation & $.707^{\star *}$ & $.605^{* *}$ & $.685^{* *}$ & $.665^{* *}$ & $.684^{* *}$ & $.504^{* *}$ & $.670^{* *}$ & 1 \\
\hline & Sig. (2-tailed) & .000 & .000 & .000 & .000 & .000 & .000 & .000 & \\
\hline & $\mathrm{N}$ & 100 & 100 & 100 & 100 & 100 & 100 & 100 & 100 \\
\hline \multicolumn{10}{|c|}{${ }^{* *}$. Correlation is significant at the 0.01 level (2-tailed). } \\
\hline \multicolumn{4}{|c|}{ *. Correlation is significant at the 0.05 level (2-tailed). } & & & & & & \\
\hline
\end{tabular}


place, promotion, price, people, process \& for $\mathrm{R}$ square and adjusted $\mathrm{R}$ square. In terms physical evidence and customer satisfaction of the values of the $\mathrm{R}$ square and adjusted $\mathrm{R}$ are higher than $0.5(0.707,0.605,0.685,0.665$, square, service marketing mix elements such $0.684,0.504$ and 0.670 respectively) service as product, place, promotion, price, people, marketing mix elements have higher strength process and physical evidence explain around of associations with customer satisfaction.

$75 \%$ of variation on customer satisfaction.

Table 4 depicts the model summary.

Table 3: Testing of Hypotheses

\begin{tabular}{|l|c|c|c|c|}
\hline Hypotheses Developed & $\begin{array}{c}\mathrm{P} \\
\text { value }\end{array}$ & $\begin{array}{c}\text { Significance } \\
\text { level }\end{array}$ & Reject $\mathrm{H}_{0}$ & Accept $\mathrm{H}_{1}$ \\
\hline Product is unrelated to Customer satisfaction & 0.000 & 0.05 & Rejected & Accepted \\
\hline Place is unrelated to Customer satisfaction & 0.000 & 0.05 & Rejected & Accepted \\
\hline Promotion is unrelated to Customer satisfaction & 0.000 & 0.05 & Rejected & Accepted \\
\hline Price is unrelated to Customer satisfaction & 0.000 & 0.05 & Rejected & Accepted \\
\hline People is unrelated to Customer satisfaction & 0.000 & 0.05 & Rejected & Accepted \\
\hline Process is unrelated to Customer satisfaction & 0.000 & 0.05 & Rejected & Accepted \\
\hline Physical evidence is unrelated to Customer satisfaction & 0.000 & 0.05 & Rejected & Accepted \\
\hline
\end{tabular}

\section{Testing of Hypotheses}

All the hypotheses set are tested and results are presented in Table 3.

Table 4: Model Summary

\section{Todel}

\begin{tabular}{|l|c|c|c|c|}
\hline Model & $\mathrm{R}$ & $\mathrm{R}$ Square & Adjusted R Square & Std. Error of the Estimate \\
\hline 1 & $.869^{\mathrm{a}}$ & .755 & .735 & 3.95649 \\
\hline
\end{tabular}

Test of hypotheses have proved that all the nulls are rejected and all the alternatives are accepted. Acceptance of all the alternatives refer to that service marketing mix such as product, place, promotion, price, people,process and physical evidence are related with customer satisfaction. In other words, service marketing mix has relationship with customer satisfaction.

\section{Regression Analysis}

Model Summary Table 4 has the output values and 99 respectively. Values of MS Regression and MS Residual are 3184.327 and 15.654 respectively. Value of $\mathrm{F}$ statistics is 203.422 that is significant. Statistics of ANOVA table is tabulated in table 5.

\section{Coefficients}

Table 6 tabulates the coefficient table. Beta values for constant, product, place, promotion, price, people, process and physical evidence are 8.539, 1.573, 1.053,

\section{Analysis of Variance}

In terms of the ANOVA table, values of SS Regression, SS Residual and SS Total are 22290.290, 1440.150 and 23730.440 respectively with degrees of freedom of 7, 92 
Impact of Service Marketing Mix on Customer Satisfaction

Table 5: ANOVA

\begin{tabular}{|l|l|c|c|c|c|c|}
\hline \multicolumn{2}{|c|}{ Model } & Sum of Squares & df & Mean Square & F & Sig. \\
\hline \multirow{3}{*}{1} & Regression & 22290.290 & 7 & 3184.327 & 203.422 & $.000^{\text {a }}$ \\
\cline { 2 - 7 } & Residual & 1440.150 & 92 & 15.654 & & \\
\cline { 2 - 7 } & Total & 23730.440 & 99 & & & \\
\hline
\end{tabular}

1.233, 1.377, $1.301,1.790$ and 1.803 respectively. In terms of the Coefficient Table 6 , all these coefficient values are significant. Table 6 tabulates the coefficient values.

\section{Conclusion}

Results of the correlation output revealed that correlations have been calculated between service marketing mix elements such as product, place, promotion, price, people, process \& physical evidence and customer satisfaction. Correlation values for service marketing mix elements such as product, place, promotion, price, people, process \& physical evidence and customer satisfaction are $0.707,0.605,0.685$, $0.665,0.684,0.504$ and 0.670 respectively. Since all these correlation values for service marketing mix elements such as product, place, promotion, price, people, process \& physical evidence and customer satisfaction are higher than $0.5(0.707,0.605,0.685,0.665,0.684,0.504$ and 0.670 respectively) service marketing mix elements have higher strength of associations with customer satisfaction. Results of test of hypotheses have proved that all the nulls are rejected and all the alternatives are accepted. Acceptance of all the alternatives refer to that service marketing mix such as product, place, promotion, price, people, process and physical evidence are related with customer satisfaction. In other words, service marketing mix has relationship with customer satisfaction. In terms of the results of regression values, $\mathrm{R}$ square and adjusted $\mathrm{R}$ square, service marketing mix

\section{Table 6: Coefficients}

\begin{tabular}{|c|c|c|c|c|c|c|}
\hline \multirow{2}{*}{\multicolumn{2}{|c|}{ Model }} & \multicolumn{2}{|c|}{ Unstandardized Coefficients } & \multirow{2}{*}{$\begin{array}{c}\begin{array}{c}\text { Standardized } \\
\text { Coefficients }\end{array} \\
\text { Beta }\end{array}$} & \multirow{2}{*}{$\mathrm{T}$} & \multirow{2}{*}{ Sig. } \\
\hline & & B & Std. Error & & & \\
\hline \multirow[t]{8}{*}{1} & (Constant) & 8.539 & 3.537 & & 2.414 & .018 \\
\hline & Product & 1.573 & .201 & .259 & 7.827 & .000 \\
\hline & Place & 1.053 & .193 & .172 & 5.466 & .000 \\
\hline & promotion & 1.233 & .185 & .214 & 6.665 & .000 \\
\hline & Price & 1.377 & .189 & .226 & 7.275 & .000 \\
\hline & People & 1.301 & .252 & .170 & 5.159 & .000 \\
\hline & Process & 1.790 & .281 & .181 & 6.379 & .000 \\
\hline & Physical evidence & 1.803 & .268 & .219 & 6.727 & .000 \\
\hline
\end{tabular}


elements such as product, place, promotion, price, people, process and physical evidence explain around $75 \%$ of variation on customer satisfaction. These results are witnessed by analysis of variance. Values of SS Regression, SS Residual and SS Total are 22290.290, 1440.150 and 23730.440 respectively with degrees of freedom of 7, 92 and 99 respectively. Values of MS Regression and MS Residual are 3184.327 and 15.654 respectively. Value of $F$ statistics is 203.422 that is significant. Beta values for constant, product, place, promotion, price, people, process and physical evidence are $8.539,1.573,1.053,1.233,1.377,1.301$, 1.790 and 1.803 respectively. Study concludes that service marketing mix have higher impact on customer satisfaction.

\section{References}

Al-Debi, A. \& Mustafa, A. (2014). The Impact Of Services Marketing Mix 7P's In Competitive Advantage To Five Stars Hotel - Case Study Amman. Paper presented at The Clute Institute International Academic Conference Orlando, Florida, USA.

Al-Muala, A. M.\& Al-Qurnch, A. B. (2012). The Usage of Internet Banking Services Among Jordanian Industries. Journal of Internet Banking and Commerce, Vol. 17, No.1, PP. 1-10.

Altman, D. G, \& Bland, J. M. (1983). Measurement in Medicine: The Analysis of Method Comparison Studies. The Statistician. Vol. 32 Iss. 1 pp. 307-317.

Dixit, A. (2004). Governance Institutions and Economic Activity, Addressed at Presidential Address to the American Economic Association, Queen's University, Canada.
Goerge, J. A. \& Kostis, A. I. (2005). Pricing objectives and pricing methods in the services sector, Journal of Services Marketing Vol. 19 No. 1, pp. 47-57

Gupta, S. L.\& Mittal, A. (2008). A study of consumer behavior aspects and brand preferences in rural India with reference to FMCG sector. Indian Institute of Management Kozhikode

Hinkle, D. E, \& Wiersma, W, and Jurs, S. G. (2003). Applied Statistics for the Behavioral Sciences. $5^{\text {th }}$ edition. Boston: Houghton Mifflin.

Homburg, C, \& Andreas, F. (2005) How Organizational Complaint Handling Drives Customer Loyalty: An Analysis of the Mechanistic and the Organic Approach. Journal of Marketing, Vol. 69, No. 3, pp. 95-114.

Ismail, M. B. M. \& Velnampy, T. (2014). Marketing Mix of Product Life Cycle (MMPLC) and Business Performance (BP) for Sarong of Royal Handloom Weaving Factory (RHWF). European Journal of Commerce and Management Research 2 (8), $168-174$.

Ismail, M. B. M. (2014), Product Mix and Sales Maximization of Rice Mill Entrepreneurs in Ampara Coastal Area, Eastern Province of Sri Lanka. Journalof Management 6 (1), $13-27$

Ismail, M. B. M. \& Safrana, M. J. (2015), Impact of marketing strategy on customer retention in handloom industry. Paper presented at International Conference: South Eastern University of Sri-Lanka 
Ismail, M. B. M. (2014), Influence of consumer promotional budget on sales in retail marketing. Paper presented at International Conference on Global Research, pp. 27- 34

Ismail, M. B. M. (2012), Corporate social responsibility in People's Bank of Sri Lanka. Paripex-Indian Journal of Research, Vol. 1. No. 11. pp. 27-30.

Ismail, M. B. M. (2012), Service Quality (SQ) and Bank Client Satisfaction (BCS) in South Eastern Region (SER) of Sri Lanka. Paper presented at International Conference on Synchronizing Management Theories and Business Practices: Challenges Ahead. Annamalai University, India, pp. 251-55

Ismail, M. B. M. (2012), Service Quality (SQ) and Bank Client Satisfaction (BCS) in South Eastern Region (SER) of Sri Lanka. Paper presented at International Conference on Business and Information 2012: Challenges \& Opportunities in the 21 st Century. University of Kelaniya, Sri Lanka, pp. 21-6.

Ismail, M. B. M. (2010), Determinants of retail customer satisfaction in banking industry in the Eastern Province of Sri Lanka. Paper presented at Annual Research Conference (ARC- 2010) on Knowledge for Reconciliation and Redevelopment, University of Jaffna, Sri Lanka, p. 82.
Kola, O. \& Akinyele, S. T. (2010). Evaluation of Effectiveness of Marketing Communication Mix Elements in Nigerian Service Sector. Pakistan Journal of Social Sciences, 7: 76-80.

Kotler, P. (2003), Marketing Management, $11^{\text {th }}$ Edition, Prentice Hall, Pearson Education.

Meidan, A. (1976). Marketing in the Service Industries: Marketing Service Indutries. Accessed from http://books.google.lk/ books?isbn $=113517458 \mathrm{X}$.

Rao, C. R. (1982). Diversity and dissimilarity coefficients: a unified approach. Theoretical Population Biology, Vol. 21 p2443.

Sarker, A., Ginn, R.,A. Nikfarjam, K. O'Connor, K. Smith, and S. Jayaraman (2012), Marketing, Journal of Management, Vol. 1. No. 1. pp. 1-10.

Yasanallah, A. \& Vahid, B. (2012). Impact of Service Marketing Mixes on Customer Perception: A Study on Eastern Bank Limited, Bangladesh. European Journal of Business and Management, Vol. 6, No. 34, pp. 2014- 16. 